\title{
Factors Affecting Success of Agricultural Marketing in Erbil, Iraq
}

\author{
Mustafa Farzenda Faris \\ Mikaeel Biro Munaf \\ Soran University \\ Faculty of Law \\ Political Science and Management \\ Accounting Department \\ Iraq \\ Cuma Akbay \\ Kahramanmaraş Sütçü Imam University \\ Agricultural Faculty \\ Department of Agricultural Economics
}

\begin{abstract}
Agricultural marketing, in general, involves moving an agricultural product from the farm to the buyer. So, agricultural marketing is a series of interconnected workouts, including production planning, growth and collection, evaluation, and packaging. The objective of this study is to investigate the factors that are important for the success of agricultural marketing. In order to achieve the goal, cross-sectional survey data obtained from 110 respondents by using a simple sampling procedure were used for this study. The obtained data were analyzed by using descriptive statistics and logistic regression method. In the light of the observational results, the priority sectors were recognized as a specific group, and the direct income support and the synchronization of all related departments were considered.
\end{abstract}

Keywords: Agricultural Marketing, Success Factors, Logistic Regression, Erbil, Iraq

\section{Introduction}

Agricultural marketing is introduced to cover the services associated with the transfer of an agricultural product from the farm to the consumer. It also refers to planning, organizing, coordinating and treating agricultural products to satisfy the farmer, the producer, and the consumer (Arndt et al., 2000). For this purpose, several interconnected exercises are connected to production, development and collection, assessment, pressing and grouping, transportation, storage, agro and livelihood management, propagation, advertising, and the deal. In fact, the term covers the entire spectrum of supply chain operations (Breimyer, 1973). However, its main ability is to coordinate these services by providing competent and capable market intelligence and to combine other operations in an integrated service with targeted results (Asogwa and Okwoche, 2012).

The agricultural marketing tends to focus on different areas such as developing infrastructures, providing information, training the farmers and intermediary about marketing and trading, and strengthening the improvement of suitable environmental policies (Frick et al., 1995). Competent marketing infrastructures such as discounting, retailing and emerging markets and warehouses are essential for efficient marketing, minimizing post-harvest losses, and reducing welfare risks. Markets play a significant role in improving areas such as wage aging, food security, and the making of national marketing links (Gupta, 1975).

Firms need to know where and how to design markets that meet the economic and social needs of society (Boyle, 1921). In general, market places may be selected incorrectly, which may result in insufficient infrastructure. Similarly, it is important not only to create a market, but also to plan how it will be managed (Lashgarara et al., 2011).

Most of the market changes that have just been completed to update the framework and ensure that maintenance and administration have come to a halt in a few years have fallen. Countries' collection markets are located in developing areas and are essentially filled with points where farmers meet with intermediaries to market the products they produce(Brennan, 1984). The discount stores of the terminals are located in major conurbations where the products are eventually passed on to customers through exchanges between wholesalers and retailers 
The characteristics and structures of the markets have changed dramatically due to changes in the urban population structure, increasing number of supermarkets, and changes in shopping behavior due to increased income levels of consumers (Anderson, 1983).

In the creation of nations, there is still the opportunity to promote agriculture through the construction of new retail windows, despite the development of grocery stores and although the regions often see advertising as a major source of revenue rather than organizations that require improvement. Within a market, both planning and income movements should be considered. In any case, maintaining order outside the market is synonymous. Authorized distributors in a market are unwilling to cooperate in raising standards when unauthorized operators face rivalries that cannot afford the cost of providing an adequate service ((Jin-hai, 2001; Eskola, 2005).

Throughout the years, significant changes have become effective to enhance the agrarian promotion framework. Numerous considerations such as the controlled markets, showcasing sheets, helpful advertising organizations, warehousing cooperatives and so on have been built up essentially to help the farmers. Different examinations demonstrated that modernization in agrarian promotion could not keep pace with the innovative selections in agribusiness. Different showcasing capacities such as evaluating, institutionalization, stockpiling, and advertise insight should be enhanced to meet present-day necessities of the farmers.

An investigation into the agrarian promotion framework is important to comprehend the complexities included and the distinguishing proof of bottlenecks with a view to giving effective administrations in the exchange of ranch items and contributions from makers to buyers. The objective of this study is to analyze the factors affecting the success of agricultural marketing in Erbil, Iraq by using cross sectional survey data and logistic regression model.

\section{Material and Methods}

In order to obtain the data needed for the present study, a questionnaire was compiled for the farmers in the province of Erbil, Iraq in 2017. The study sample consisted of 110 farmers. The questionnaire was scored using structured 3-point battery with modified likert scale as disagree (1), agree somewhat (2), and agree (3). The data collected through the investigation tool were analyzed on the basis of each research question and hypothesis. Descriptive statistics including frequency and percentage was used to examine the research questions. Also, logistic regression was used to analyze the hypotheses. SPSS software version 22 was used to analyze the collected data.

\section{Results and Discussions}

Based on the results, $66 \%$ of the respondents had completed lower secondary education, while $44 \%$ who had a degree or diploma worked as farmers or were employed by farmers. As shown, $47.3 \%$ of the farmers had a salary of less than 450,000 Iraqi dinars, and 35.5\% earned between 450,000 and 600,000 Iraqi dinars, while the remaining $17.2 \%$ of the farmers had a salary of more than 600,000 Iraqi dinars. By looking at Table 1, it can be seen that $9.1 \%$ of the farmers had an experience of less than 5 years, $54.5 \%$ between 5 to 10 years, and the remaining $36.4 \%$ of the farmers had an experience of more than 10 years. According to the results, the largest group of the participants of the study (41.8\%) belonged to the age group 25-30 years. This may indicate that the reason for attracting and hiring middle-aged people is to exploit them for a long time and equip them with skills and great experiences over time.

Table 1. Socio Demographic Characteristics of Respondents

\begin{tabular}{|l|l|l|l|}
\hline Variables & Frequency & $\%$ \\
\hline \multirow{4}{*}{ Education } & Primary & 38 & 34.5 \\
\cline { 2 - 4 } & Secondary & 28 & 25.5 \\
\cline { 2 - 4 } & High school & 26 & 23.5 \\
\cline { 2 - 4 } & College or university & 18 & 16.5 \\
\hline \multirow{3}{*}{$\begin{array}{l}\text { Income Group } \\
\text { Iraqi Dinar) }\end{array}$} & Less than 450,000 & 52 & 47.3 \\
\cline { 2 - 4 } & $450,000-600,000$ & 39 & 35.5 \\
\cline { 2 - 4 } & More than 600,000 & 19 & 17.2 \\
\hline \multirow{5}{*}{ Experiences } & Less than 5 years & 10 & 9.1 \\
\cline { 2 - 4 } & $5-10$ years & 60 & 34.5 \\
\cline { 2 - 4 } & More than 10 years & 40 & 36.4 \\
\hline \multirow{3}{*}{ Group } & Less than 25 & 24 & 21.8 \\
\cline { 2 - 4 } & $25-30$ & 46 & 31.8 \\
\cline { 2 - 4 } & More than 30 & 40 & 36.4 \\
\hline
\end{tabular}


In order to demonstrate the success of agricultural marketing factors according to the respondents, descriptive statistics were used to analyze the data, and the results for each variable were expressed as mean and standard deviation. As shown in Table 2, 44.5\% of the farmers disagreed, 38.2\% somewhat agreed, and $17.3 \%$ agreed over "agriculture should be treated as a priority sector". Besides, $12.7 \%$ of the farmers selected disagree, and $29.1 \%$ somewhat agree regarding "small and marginal farmers should be recognized as a special group". In terms of the item "direct income support should be given to small and marginal farmers", $12.7 \%$ of the farmers disagreed, $36.4 \%$ somewhat agreed, and $50.9 \%$ agreed (Table 3.2). Also, $19.1 \%$ of the farmers chose disagree, and $42.7 \%$ agree regarding "efforts should be done for value enhancement of agro products". Taking a look at Table 2 reveals that $6.4 \%$ of the farmers chose disagree and $72.7 \%$ agree regarding "trade policies should be designed for sustainable agriculture growth and protection of agriculture markets". According to the results presented in Table 2, 14.5\% of the farmers selected disagree and 54.5\% agree with regard to the item "the government should emphasize agriculture-oriented research and education". Moreover, $15.5 \%$ of the respondents chose disagree and $36.4 \%$ agree regarding the item "all related departments should be synchronized for better execution of agricultural policies". Furthermore, $10.9 \%$ of the farmers selected disagree, and $48.2 \%$ agree regarding "Non-farm rural farmers should be increased".

Table 2. Factors Affecting Success of Agricultural Marketing

\begin{tabular}{|c|c|c|c|c|c|}
\hline \multicolumn{2}{|l|}{ Variables } & Frequency & $\%$ & Mean & SD \\
\hline \multirow{3}{*}{$\begin{array}{l}\text { Agriculture should be } \\
\text { treated as a priority sector }\end{array}$} & Disagree & 49 & 44.5 & \multirow{3}{*}{1.73} & \multirow{3}{*}{0.741} \\
\hline & Somewhat agree & 42 & 38.2 & & \\
\hline & Agree & 19 & 17.3 & & \\
\hline \multirow{3}{*}{$\begin{array}{l}\text { Small and marginal } \\
\text { farmers should be } \\
\text { recognized as a special } \\
\text { group }\end{array}$} & Disagree & 14 & 12.7 & \multirow{3}{*}{2.45} & \multirow{3}{*}{0.712} \\
\hline & Somewhat agree & 32 & 29.1 & & \\
\hline & Agree & 64 & 59.2 & & \\
\hline \multirow{3}{*}{$\begin{array}{l}\text { Direct income support } \\
\text { should be given to small } \\
\text { farmers }\end{array}$} & Disagree & 14 & 12.7 & \multirow{3}{*}{2.38} & \multirow{3}{*}{0.704} \\
\hline & Somewhatagree & 40 & 36.4 & & \\
\hline & Agree & 56 & 50.9 & & \\
\hline \multirow{3}{*}{$\begin{array}{l}\text { Efforts should be done for } \\
\text { value enhancement of } \\
\text { agro products }\end{array}$} & \begin{tabular}{|l|} 
Disagree \\
\end{tabular} & 21 & 19.1 & \multirow{3}{*}{2.24} & \multirow{3}{*}{0.753} \\
\hline & Somewhat agree & 42 & 38.2 & & \\
\hline & Agree & 47 & 42.7 & & \\
\hline \multirow{3}{*}{$\begin{array}{l}\text { Trade policies should be } \\
\text { designed for sustainable } \\
\text { agriculture growth and } \\
\text { protection of agriculture } \\
\text { markets }\end{array}$} & Disagree & 7 & 6.4 & \multirow[b]{3}{*}{2.66} & \multirow[b]{3}{*}{0.595} \\
\hline & Somewhat agree & 23 & 20.9 & & \\
\hline & Agree & 80 & 72.7 & & \\
\hline \multirow{3}{*}{$\begin{array}{l}\text { The government should } \\
\text { emphasize agriculture- } \\
\text { oriented research and } \\
\text { education }\end{array}$} & Disagree & 16 & 14.5 & \multirow{3}{*}{2.40} & \multirow{3}{*}{0.732} \\
\hline & Somewhat agree & 34 & 30.9 & & \\
\hline & Agree & 60 & 54.5 & & \\
\hline \multirow{3}{*}{$\begin{array}{l}\text { Synchronization of all } \\
\text { related departments }\end{array}$} & \begin{tabular}{|l} 
Disagree \\
\end{tabular} & 17 & 15.5 & \multirow{3}{*}{2.21} & \multirow{3}{*}{0.692} \\
\hline & Somewhat agree & 53 & 48.2 & & \\
\hline & Agree & 40 & 36.4 & & \\
\hline \multirow{3}{*}{$\begin{array}{l}\text { Non- farm rural } \\
\text { employment should be } \\
\text { increased. }\end{array}$} & Disagree & 12 & 10.9 & \multirow{3}{*}{0.69} & \multirow{3}{*}{0.675} \\
\hline & Somewhat agree & 45 & 40.9 & & \\
\hline & Agree & 53 & 48.2 & & \\
\hline
\end{tabular}

\section{Results of the Logistic Regression Model for the Success of Agricultural Marketing}

According to model results, The Nagelkerke $\mathrm{R}^{2}$ was 0.640 and representing a rather strong relationship among the predictors and the variable (Table 3). The model H-L statistic also showed that the model is a quite good fit. Overall,93.6\% of the cases were correctly classified. Wald statistics illustrated that the model with indicators is a significantly better model. In order to use the variables given in Table 2 as independent variables in the logistic model, those who did not agree were coded as 0 and those who partially or fully participated as 1 . The results of statistically significant coefficient showed that the item "Agriculture should be treated as a priority sector" has a positive effect on the "Success of Agricultural Marketing". 
Based on the statistically significant coefficients, agricultural marketing success of the producers who advocate that agriculture should be considered as a priority sector is higher than other producers. Based on the statistically significant coefficient, the participation of farmers in the opinion that "small and marginal farmers should be considered as a special group" had a positive effect on the "Success of Agricultural Marketing". The result of odds ratio shows that the agricultural success of farmers who agree that small and marginal farmers should be considered as a special group is 17.75 times higher than other farmers. The output of the statistically significant coefficient represented that "Direct income support should be given to small and marginal farmers" has a positive effect on the "Success of Agricultural Marketing". In addition, the results indicated that the odds ratio of direct income support was 4.94 times more likely to be involved in the Success of Agricultural Marketing. As the results of statistically significant coefficient represented that "Synchronization of all related departments for better execution of Agricultural Policy" has a positive effect on the "Success of Agricultural Marketing". Furthermore, the results indicated that the agricultural marketing success of farmers who think that all relevant departments should be synchronized for better implementation of agricultural policy is 7.11 times higher than other farmers.

Table 3. The Logistic Regression Model for the Success of Agricultural Marketing

\begin{tabular}{|c|c|c|c|c|c|}
\hline Variables & Coefficient & Sta. Error & $\begin{array}{l}\text { Wald } \\
\text { Test }\end{array}$ & P-value & $\begin{array}{l}\text { Odd } \\
\text { Ratio }\end{array}$ \\
\hline Constant & $-15.772^{* * *}$ & 5.014 & 9.894 & 0.002 & 0.00 \\
\hline Priority sector & $1.450^{* *}$ & 0.683 & 4.506 & $\mathbf{0 . 0 3 4}$ & 4.26 \\
\hline Recognized as a special group & $2.819^{* *}$ & 1.149 & 6.015 & 0.014 & 16.75 \\
\hline Direct income support & $1.598^{* * * *}$ & 0.717 & 4.961 & 0.026 & 4.94 \\
\hline $\begin{array}{l}\text { Value enhancement of agro } \\
\text { products }\end{array}$ & 0.804 & 0.680 & 1.396 & 0.237 & 2.23 \\
\hline Trade policies & -1.144 & 0.770 & 2.208 & 0.137 & 0.31 \\
\hline $\begin{array}{l}\text { Agriculture oriented research and } \\
\text { education }\end{array}$ & 0.608 & 0.563 & 1.169 & 0.280 & 1.83 \\
\hline $\begin{array}{l}\text { Synchronization of all related } \\
\text { departments }\end{array}$ & $1.962^{* *}$ & 0.902 & 4.727 & $\mathbf{0 . 0 3 0}$ & 7.11 \\
\hline Non- farm rural employment & $1.130^{*}$ & 0.655 & 2.973 & $\mathbf{0 . 0 8 5}$ & 3.09 \\
\hline$-2 \log$ likelihood & \multicolumn{5}{|l|}{40.021} \\
\hline Nagelkerke $\mathrm{R}^{2}$ & \multicolumn{5}{|l|}{0.640} \\
\hline$\chi 2$ ( p:value) & \multicolumn{5}{|c|}{$47.606(0.000)$} \\
\hline
\end{tabular}

\section{Conclusions and Recommendations}

Agriculture in the broadest sense means activities geared to the use of natural resources for the well-being of human beings; therefore, it covers all essential generations. However, it is mostly used to indicate producing crops and raising animals. Marketing means a sequence of exercises associated with the transportation of goods from the place of production to the place of use. It covers all the activities related to the creation of time, place, form and benefits of ownership. The research includes all corporations and organizations and helps to develop food, raw materials and their subordinates produced on the farm. It is necessary to carry out studies on the marketing system for agricultural products to understand the complexity and the identification of bottlenecks to provide efficient services for the transmission of agricultural products from producers to consumers. Statistical analyses were used for categorical variables to indicate frequencies and percentages. Logistic regression was utilized to determine the association among categorical variables. According to results, direct income support, development of appropriate trade policies, implementation of agriculturaloriented training and research, increasing non-agricultural rural employment and increasing the coordination of agricultural institutions will contribute positively to the success of agricultural marketing. In addition, appropriate agricultural supports should be provided to small and medium-sized farmers and relevant institutions that can enable agricultural strategies to work more effectively should be developed.

\section{References}

Anderson, K., 1983. Economic Growth, Comparative Advantage and Agricultural Trade of Pacific Rim. Review of Marketing and Agricultural Economics, Australian Agricultural and Resource Economics Society, 51(03): 118. 
Asogwa, B.C. and Okwoche, V.A., 2012. Marketing of agricultural produce among rural farm households in Nigeria: The case of sorghum marketing in Benue State. International journal of Business and social science, 3(13):269277.

Arndt, C., Jensen, H.T., Robinson, S. and Tarp, F., 2000. Marketing Margins and Agricultural Technology in Mozambique. The Journal of Development Studies, 37(1):121-137.

Boyle, J.E., 1921. Marketing of agricultural products. The American Economic Review, 11(2): 207-213.

Breimyer, H.F., 1973. The economics of agricultural marketing: A survey. Review of Marketing and Agricultural Economics, 41(4): 115-165.

Brennan, J.P., 1984. Measuring the contribution of new varieties to increasing wheat yields. Review of Marketing and Agricultural Economics, 52(3): 175-195.

Eskola, E., 2005. Agricultural marketing and supply chain management in Tanzania: A case study. Working Paper Series No. 16. Success under Duress: a Comparison of the Indigenous African and East African Asian Entrepreneurs.

Frick, M.J., Birkenholz, R.J. and Machtmes, K., 1995. 4-H member knowledge and perception of agriculture. Journal of Agricultural Education, 36(3): 43-49.

Gupta, A.P., 1975. Marketing of agricultural produce in India.Vora And Co., Publishers Pvt. Ltd.

Jin-hai, X.U., 2001.Probing into the Contemporary Marketing Problems of China's Agricultural Products Economic Problems, 2:14. "http://en.cnki.com.cn/Article_en/CJFDTOTAL-JJWT200102014.htm"

Lashgarara, F., Mohammadi, R. and Najafabadi, M.O., 2011.Identifying appropriate information and communication technology (ICT) in improving marketing of agricultural products in Garmsar City, Iran. African Journal of Biotechnology, 10(55): 11537-11540. 